\title{
Effect of herbicides in the oxidative stress in crop winter species
}

\author{
CARLA ALVES ${ }^{1,2}$, EDUARDA COSTA ${ }^{2}$, JESSICA R. SOFIATTI ${ }^{2}$, CESAR T. FORTE ${ }^{1}$, FÁBIO \\ L. WINTER ${ }^{1}$, CINTHIA M. HOLZ ${ }^{1}$, ROSILENE R. KAIZER ${ }^{1,2}$ and LEANDRO GALON ${ }^{1}$
}

\author{
${ }^{1}$ Programa de Pós-Graduação em Ciência e Tecnologia Ambiental, Universidade Federal \\ da Fronteira Sul, Rodovia RS 135, Km 72, 99700-970 Erechim, RS, Brazil \\ ${ }^{2}$ Instituto Federal de Educação, Ciência e Tecnologia do Rio Grande do Sul, Campus \\ Sertão, Rodovia RS 135, Km 25, 99170-000 Sertão, RS, Brazil
}

Manuscript received on June 30, 2017; accepted for publication on December 8, 2017

\begin{abstract}
Most herbicides applied in crop field, stay in the soil for a period, affecting next crop or even the plants using as green manure. Nowadays, the use of herbicides grow to increase productivity, mainly in the grain producing region north of Rio Grande do Sul state. The objective of this study was to evaluate the effects of herbicides fomesafen and sulfentrazone on antioxidant system in Avena sativa ${ }^{1}$, Vicia sativa ${ }^{2}$, Raphanus sativus and Lupinus albus. The plants were exposed to varying concentrations of fomesafen ${ }^{3}(0,0.125$, 0.25 and $\left.0.5 \mathrm{~kg} \mathrm{ha}^{-1}\right)$ and sulfentrazone $\left(0,0.3,0.6\right.$ and $\left.1.2 \mathrm{~kg} \mathrm{ha}^{-1}\right)$. For this, the activities of, ascorbat peroxidase, catalase and guaiacol enzymes were analyzed, and the levels of MDA were quantificated. Fomesafen and sulfentrazone promoted alterations in balance of plants generating oxidative stress and elicited the response of the antioxidant system of plants, mainly in the high doses of fomesafen, for the species $V$. sativa and $R$. sativus. At the same time, the $1,2 \mathrm{~kg} \mathrm{ha}^{-1}$ dose of sulfentrazone generated lipid peroxidation for $V$. sativa, R. sativus and L. albus. Additionally, A. sativa was the species that demonstrated low alterations on antioxidant system with the exposure to herbicide fomesafen and sulfentrazone. Thus, we can we can suggest that the species present a better response in defense of the oxidative stress generated by the herbicides.
\end{abstract}

Key words: Catalase, enzymes, agricultural plants, PROTOX system.

\footnotetext{
${ }^{1}$ A. sativa demonstrated fewer alterations on antioxidant system on both herbicides exposure.

${ }^{2} V$. sativa, $R$. sativus and L. albus were negative affected by sulfentrazone in the dose

$1.2 \mathrm{~kg} \mathrm{ha}^{-1}$, showing an increased on levels of lipid peroxidation.
}

${ }^{3}$ Fomesafen and sulfentrazone cause different reactions on antioxidant system in A. sativa, V. sativa, R. sativus and L. albus.

Correspondence to: Rosilene Rodrigues Kaizer

E-mail: rosikaizer@gmail.com 


\section{INTRODUCTION}

Brazil has recently been the largest consumer market of agrochemicals worldwide, and herbicides represent $69 \%$ of the total consumption of such chemicals (SINDIVEG 2016). In crops field, many herbicides are used to control weed, however, these toxicants can remain in the soil for long periods and can contaminate rivers and subterranean waters. Thus, these chemicals can promote several ecotoxicological and environmental effects, as they elicit alterations on antioxidant system in nontarget organisms, as on sensitive plants.

Some herbicides like fomesafen and sulfentrazone are inhibitors of protoporphyrinogen oxidase (PROTOX) system. Mechanism of action of PROTOX inhibitors herbicides are involved in the inhibition of the protoporphyrinogen oxidase enzyme, which acts on the oxidation of protoporphyrinogen to protoporphyrin IX (precursor of chlorophyll) and heme clusters. Enzyme PROTOX inhibition promotes accumulation of protoporphyrinogen in chloroplast, so it diffuses into the cytoplasm and then form protoporifirin IX. In the cytoplasm and in the presence of light the protoporifirin IX interacts with oxygen generating an oxygen singlet. This $\mathrm{O}_{2}$ in the singlet state is responsible for peroxidation of lipids in cell membranes. As a cascade effect, free radicals are formed resulting in the degradation of lipids and proteins, leading to loss of chlorophyll, carotenoids and disruption of cell membranes (Oliveira et al. 2002, Mateus et al. 2004). Various abiotic stresses lead to the overproduction of Reactive Oxygen Species (ROS) in plants, which are reactive and toxic causing damage to proteins, lipids, carbohydrates and DNA, which ultimately results in oxidative stress (Gill and Tuteja 2010). This mechanism disrupts the physiology of plant and causes loss in the plants weight, photosynthesis and productivity. One of this alterations can promote the oxidative stress in green manures under residual herbicide in the soil.

Level of stress in a cell is determined by the amount of ROS present in the forms of superoxide, hydrogen peroxideandhydroxyl radicals. Enzymatic and non-enzymatic antioxidative systems in plants are present in various cell compartments. Among the main enzymatic antioxidant defenses, are superoxide dismutase (SOD), ascorbate peroxidase (APX), guaiacol peroxidase (GPX) and catalases (CAT), which promote the control of ROS levels. Thus, the knowledge of role of SOD, APX, CAT and peroxidases enzymes defines the status of the antioxidant system, which is very important in the reduction of the levels of ROS in the cells (Apel and Hirt 2004, Cavalcanti et al. 2004), avoiding the oxidative stress promotion. It is necessary to know how herbicides affect the plants used as green manure, since they will contact residues of herbicides in the soil, derived from the preceding crop.

Actually, associated to the use of herbicides the technique of green manure promotes the improvement of physical and chemical properties in soil. They have great inhibitory power over weeds, even after cutting and forming a mulch on the soil. The mulch protects the soil from solar radiation, dissipates the energy of rainfall impact, reduces water evaporation, and increases the cycling of nutrients, as well as being an alternative to the control of weeds, reducing the use of herbicides (Mateus et al. 2004). Considering common winter species used in crop fields on Rio Grande do Sul, A. sativa, $V$. sativa, $R$. sativus and $L$. albus act as green manures and improve the soil properties. Thus, the objective of this study was to evaluate if the herbicides fomesafen and sulfentrazone, caused oxidative stress to Avena sativa, Vicia sativa, Raphanus sativus and Lupinus albus. 


\section{MATERIALS AND METHODS}

Experiments were conducted under greenhouse conditions in Federal University of the Fronteira Sul (UFFS), Erechim, RS, Brazil. The treatments were composed of a combination of Avena sativa, Vicia sativa, Raphannus sativus, and Lupinus albus, and different concentrations of fomesafen $\left(0.0,0.125,0.25,0.5 \mathrm{~kg} \mathrm{ha}^{-1}\right)$, or sulfentrazone (0.0, $0.3,0.6$ and $1.2 \mathrm{~kg} \mathrm{ha}^{-1}$ ), applied in pre-emergence of cultures. These doses are half, the dose and double dose that has used in fields. Treatment were arranged with complete randomized blocks with four replications. All determinations were performed in three replicates.

After the filling polyethylene pot $\left(8 \mathrm{dm}^{3}\right)$ with alum-ferric humic Red Latosol (EMBRAPA 2013) from the herbicide free area. Soil fertility correction performed based on the chemical analysis of the soil and according to the technical recommendations for the cultures involved in the trials (ROLAS 2016). After one-day herbicides fomesafen and sulfentrazone were applied using a precision cost sprayer, equipped with two spray tips of the TT 110.02 series, which sprayed a volume of $150 \mathrm{~L}$ ha ${ }^{-1}$. Irrigation controlled daily in the experimental units, maintaining humidity around $80 \%$ of field capacity.

After the harvest plants shoots were freezing in liquid nitrogen. Then the shoots were macerated with liquid nitrogen, and used to all analysis. The exceeding material was stocked in ultra freezer $-80^{\circ} \mathrm{C}$.

For the CAT assay, the homogenization of fresh tissue material in a solution containing 50 $\mathrm{mM} \mathrm{KH} \mathrm{PO}_{4} / \mathrm{K}_{2} \mathrm{HPO}_{4}$ (pH 7.0), $10 \mathrm{~g} \mathrm{~L}^{-1} \mathrm{PVP}, 0.2$ mM EDTA and $10 \mathrm{~mL} \mathrm{~L}^{-1}$ Triton X-100. Than the homogenate was centrifuged at $12000 \times \mathrm{g}$ at $4^{\circ} \mathrm{C}$ for $20 \mathrm{~min}$. Supernatant was used to determine catalase activity, which was assayed according to the modified method of (Aebi 1984) by monitoring the disappearance of $\mathrm{H}_{2} \mathrm{O}_{2}$ by measuring the decrease in absorbance at $240 \mathrm{~nm}$. In a reaction mixture with a final volume of $2 \mathrm{~mL}$ containing 15 $\mathrm{mM} \mathrm{H} \mathrm{H}_{2} \mathrm{O}_{2}$ in $50 \mathrm{mM} \mathrm{K}$-phosphate buffer ( $\mathrm{pH}$ 7.0) and $30 \mu \mathrm{L}$ extract. Catalase activity was expressed as percentage $(\%)$ of difference between control without herbicide.

Guaiacol peroxidase activity was determined using guaiacol as substrate (Zeraik et al. 2008). The reaction mixture contained $1.0 \mathrm{~mL}$ of potassium phosphate buffer (100 mM, pH 6.5), 1.0 $\mathrm{ml}$ guaiacol $(15 \mathrm{mM})$ and $1.0 \mathrm{ml} \mathrm{H}_{2} \mathrm{O}_{2}(3 \mathrm{mM})$. After homogenization, $50 \mu \mathrm{L}$ of the plant extract was added to this solution. The activity of the enzyme was measured by oxidation of guaiacol to tetraguaiacol by increasing the absorbance at 470 $\mathrm{nm}$. The results were expressed as percentage (\%) of difference between control without herbicide.

For determination of APX activity, plants extract were homogenized in a $50 \mathrm{mM} \mathrm{KH_{2 }} \mathrm{PO}_{4} /$ $\mathrm{K}_{2} \mathrm{HPO}_{4}(\mathrm{pH}$ 7.0) containing $1 \mathrm{mM}$ EDTA and $2 \%$ PVP, $\mathrm{pH} 7.8$, at a ratio of $1: 3(\mathrm{w} / \mathrm{v})$. Than the homogenate was centrifuged at $13000 \mathrm{xg}$ for $20 \mathrm{~min}$ at $4^{\circ} \mathrm{C}$, and the supernatant was used for enzyme activity. Enzyme activity was assayed according to the modified method of Zhu et al. (2004). The reaction mixture, at a total volume of 2 $\mathrm{mL}$, consisted of $25 \mathrm{mM}$ sodium phosphate buffer (pH 7.0), $0.1 \mathrm{mM}$ EDTA, $0.25 \mathrm{mM}$ ascorbate, 1.0 $\mathrm{mM} \mathrm{H} \mathrm{O}_{2}$ and $100 \mathrm{~mL}$ extract. $\mathrm{H}_{2} \mathrm{O}_{2}$ dependent oxidation of ascorbate was followed by a decrease in absorbance at $290 \mathrm{~nm}\left(\mathrm{E}^{1 / 4} 2.8 \mathrm{Mm}^{-1} \mathrm{~cm}^{-1}\right)$. Ascorbate peroxidase activity was expressed as $\mathrm{mmol}$ oxidized ascorbate/min/mg protein.

Levels of lipid peroxidation in the plants were determined by measuring malondialdehyde (MDA) content from the thiobarbituric acid (TBA) (Elmoshaty et al. 1993. The shoots were homogenized in $0.2 \mathrm{M}$ citrate $\square$ phosphate buffer, $\mathrm{pH}$ 6.5. The homogenate was filtered through two layers of paper filter and then centrifuged at $20000 \mathrm{~g}$ at $4^{\circ} \mathrm{C}$ for 15 min. One milliliter of the supernatant fraction was added to an equal volume of $20 \%$ TCA containing 
$0.5 \% \mathrm{TBA}$. Tubes were placed in a $95^{\circ} \mathrm{C}$ water bath for $40 \mathrm{~min}$, and then immediately cooled on ice for $15 \mathrm{~min}$. Samples were centrifuged at $10000 \mathrm{~g}$ for $15 \mathrm{~min}$. The absorbance of the supernatant at 532 $\mathrm{nm}$ was read and corrected for unspecific turbidity by subtracting the value at $600 \mathrm{~nm}$. MDA values expressed in nmol MDA/mg protein.

Linear or non-linear regressions were applied to evaluate the effect of herbicide rates on the species studied, $\mathrm{p}<0.05$.

\section{RESULTS AND DISCUSSION}

Fomesafen causes a significant decrease in CAT activity in $V$. sativa. R. sativus and L. albus, related to the herbicide concentration increase. On other hand, after the fomesafen exposure the CAT activity increased significantly for $A$. sativa, with the increase of herbicide concentration. Thus, for both cases we found a dose dependent effect. For $R$. sativus, in the higher dose of fomesafen occurs the plant death (Fig. 1).

Sulfentrazone exposure promotes an increased in CAT activity for both $R$. sativus and L. albus. Interesting result was observed in $R$. sativus that shows significant increase comparing the herbicide concentration increase (Fig. 2). However, higher the herbicide concentration CAT activity decreased considerably for $A$. sativa and $V$. sativa.

A. sativa, L. albus and $R$. sativus show a significant reduction on Guaiacol peroxidase activity, on the three doses of fomesafen applied. However, $V$. sativa showed an enhanced in the GPX activity when increased the herbicide concentration. In fact, L. albus in the dose of 0.125 and $0.5 \mathrm{~kg} \mathrm{ha}{ }^{-1}$ had a decrease in activity to $35 \%$ and $33 \%$, when compared to control group (Fig. $3)$, respectively. Herbicide sulfentrazone causes a significant decreased on GPX activity for $A$. sativa

\section{Fomesafen}

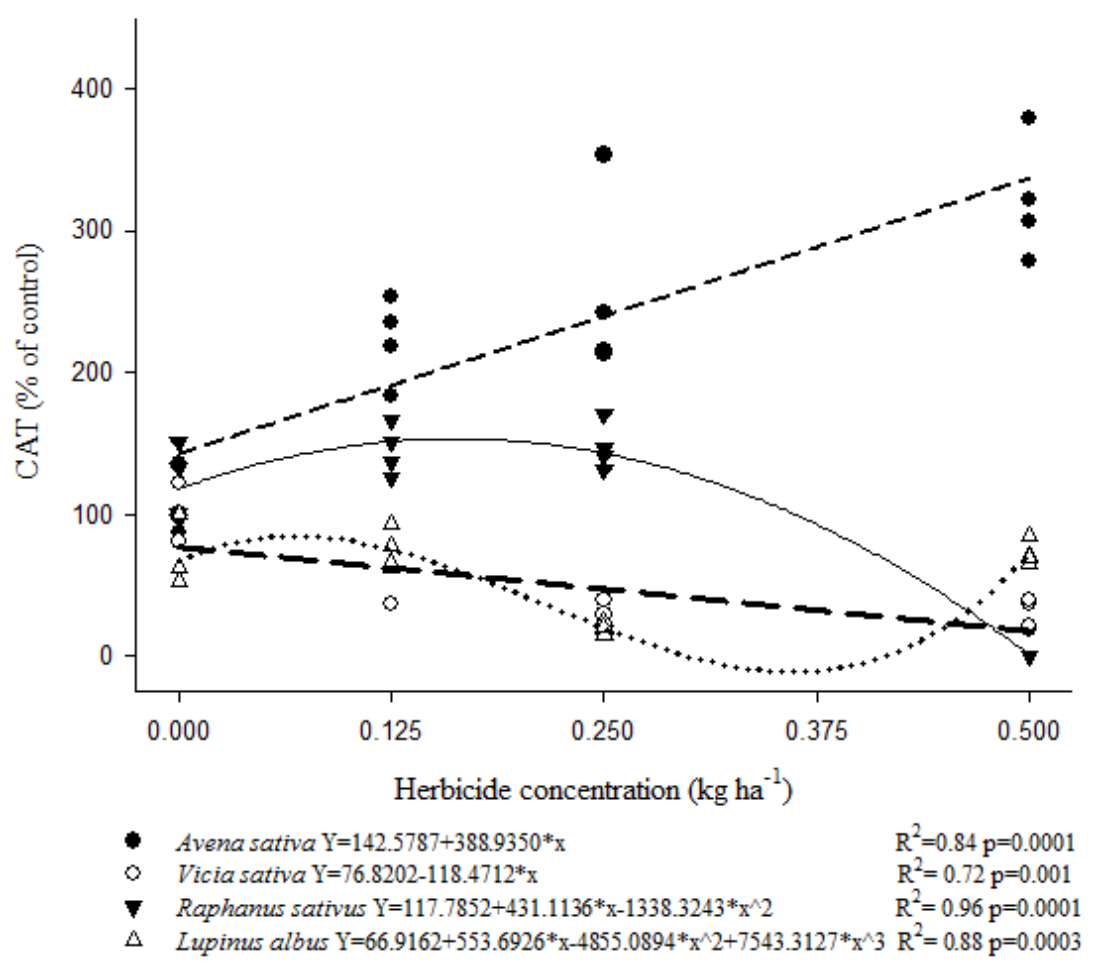

Figure 1 - Effect of fomesafen on catalase (CAT) activity in different crop plants. 


\section{Sulfentrazone}

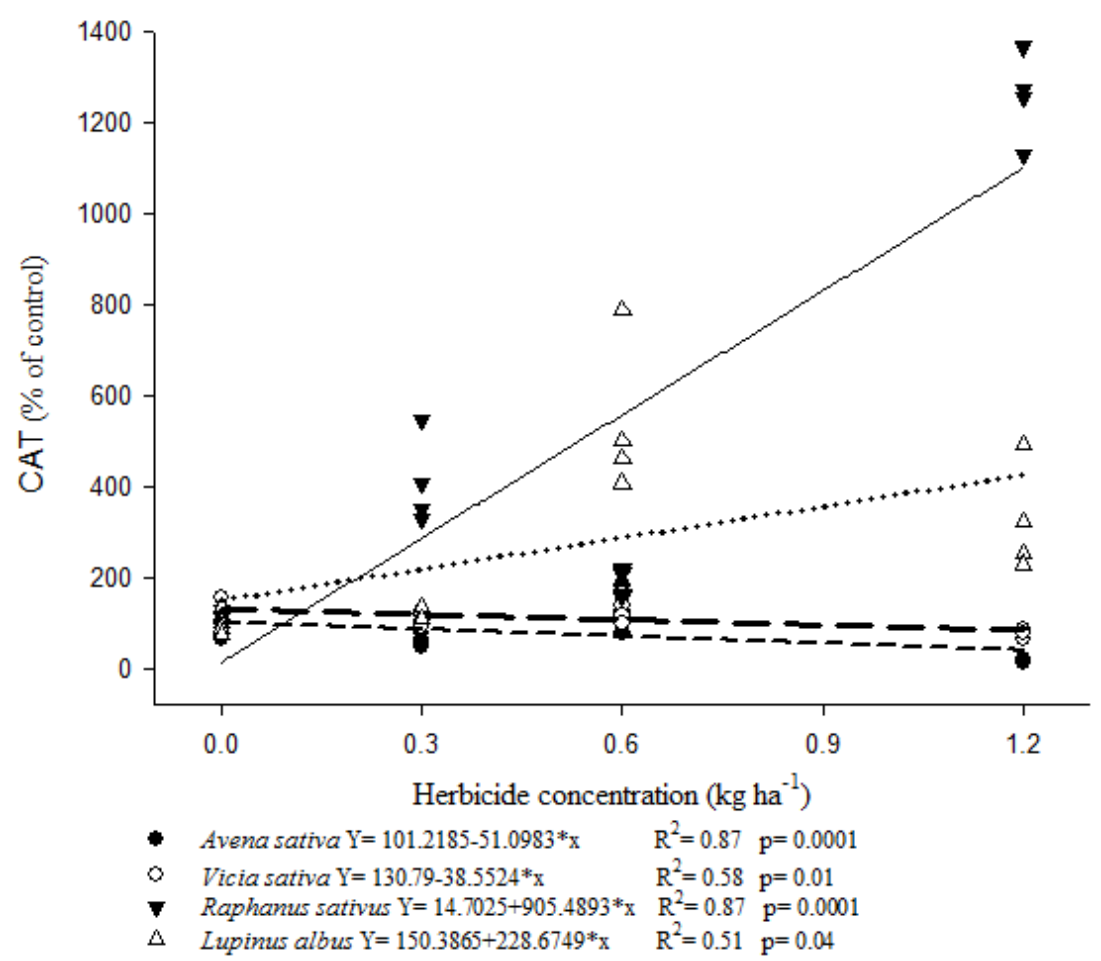

Figure 2 - Effect of sulfentrazone on catalase (CAT) activity in different crop plants.

\section{Fomesafen}

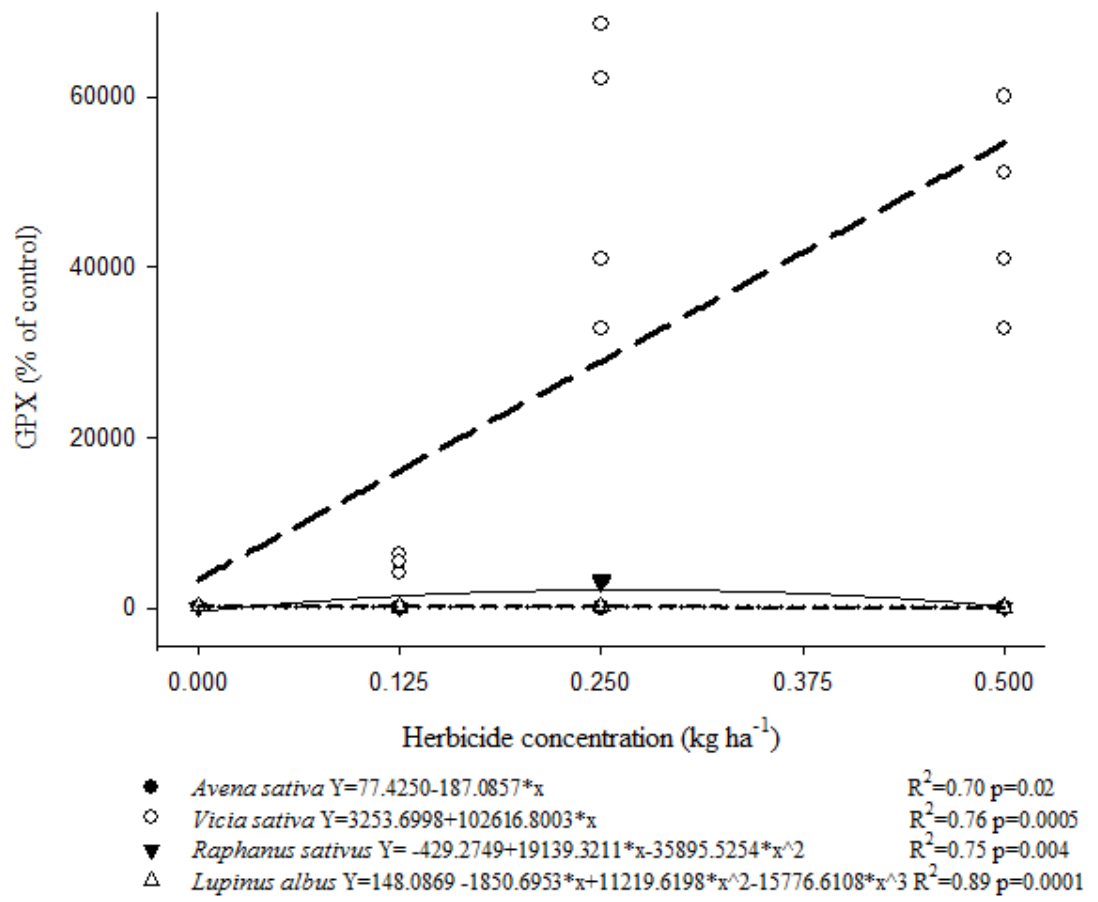

Figure 3 - Effect of fomesafen on Guaiacol peroxidase (GPX) activity in different crop plants. 
(37\%), R. sativus (89\%), L. albus (95\%), and $V$. sativa (Fig. 4).

Lipid peroxidation expressed in terms of MDA formed in shoot tissues of the species exposed to both herbicides, show different results for each plants. In $V$. sativa clearly was observed that the levels of lipid peroxidation increased significantly in according to the enhancement of the fomesafen concentration. On the other hand, $A$. sativa, R. sativus and L. albus, shows a significant decrease in the lipid peroxidation with increasing the concentration of fomesafen. (Fig. 5). Lipid peroxidation promoted by sulfentrazone, just $A$. sativa shows a significant decrease in the level of MDA. R. sativus and L. albus have an increase in the levels of MDA when herbicide concentration increased (Fig. 6).

The presence of fomesafen in the soil caused and increase in APX activity only in $V$. sativa. On the other hand, L. albus and A. sativa and R. sativus showed a decreased in the activity of APX when increased the herbicide concentration (Fig. 7). At same time, sulfentrazone concentration exposure decreased APX activity in A. sativa, L. albus and $V$. sativa. This fact could not observed to $R$. sativus, which shows an increased on enzyme activity (Fig. 8).

This study revealed the effect of herbicide exposure in the promotion of oxidative stress and response of antioxidant defense mechanism in species used as green manure. It is clear fomesafen and sulfentrazone toxicity depends not only on the concentration, but also on species used.

Among the main enzymes of plants antioxidant defense mechanism the most importante is Catalase. CAT enzyme are tetrameric heme containing enzymes with the potential directly dismutate $\mathrm{H}_{2} \mathrm{O}_{2}$ into $\mathrm{H}_{2} \mathrm{O}$ and $\mathrm{O}_{2}$, indispensable for ROS detoxification during stressed condition (Garg and Manchanda 2009). CAT has one of the highest turnover rates for all enzymes: one molecule of

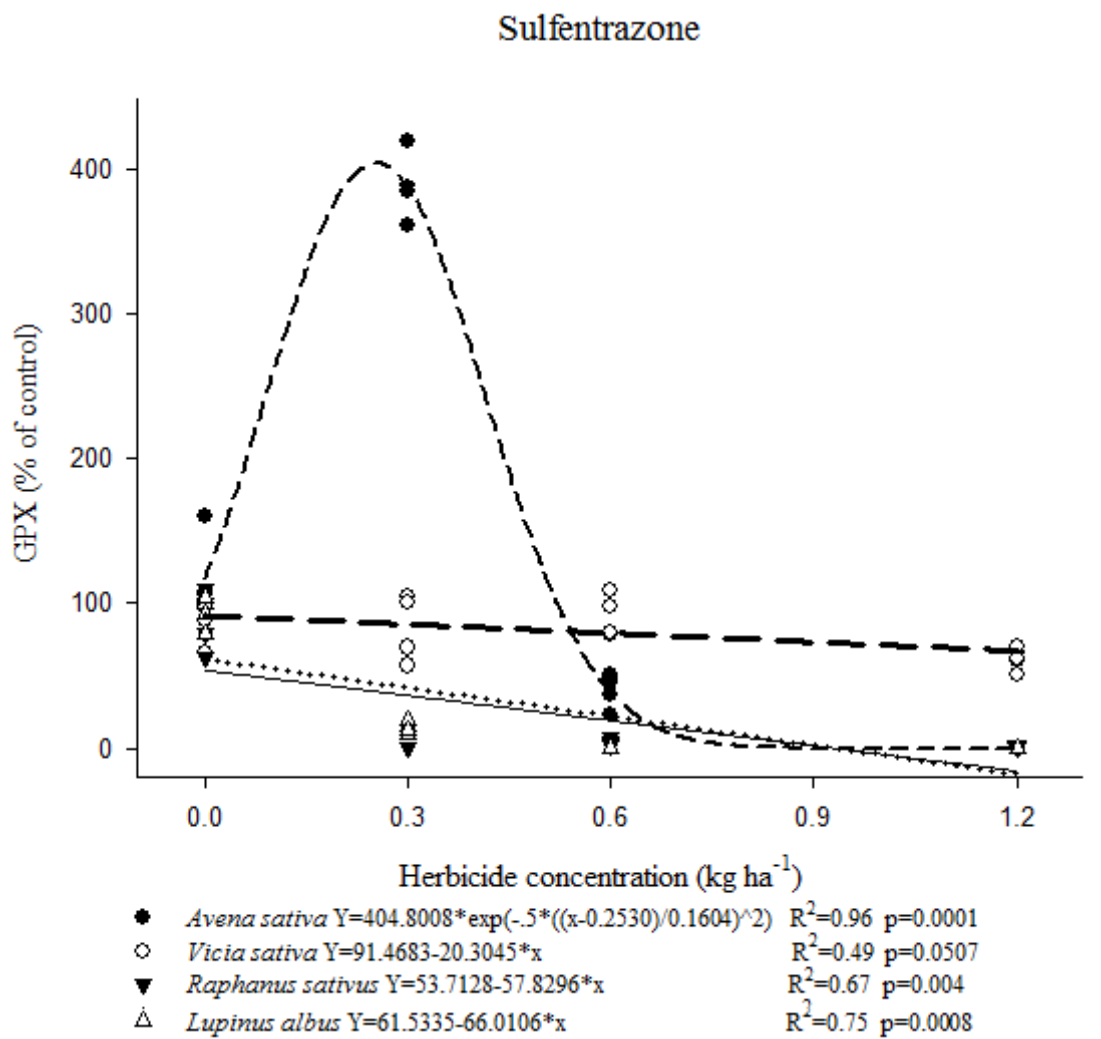

Figure 4 - Effect of sulfentrazone on Guaiacol peroxidase (GPX) activity in different crop plants. 


\section{Fomesafen}

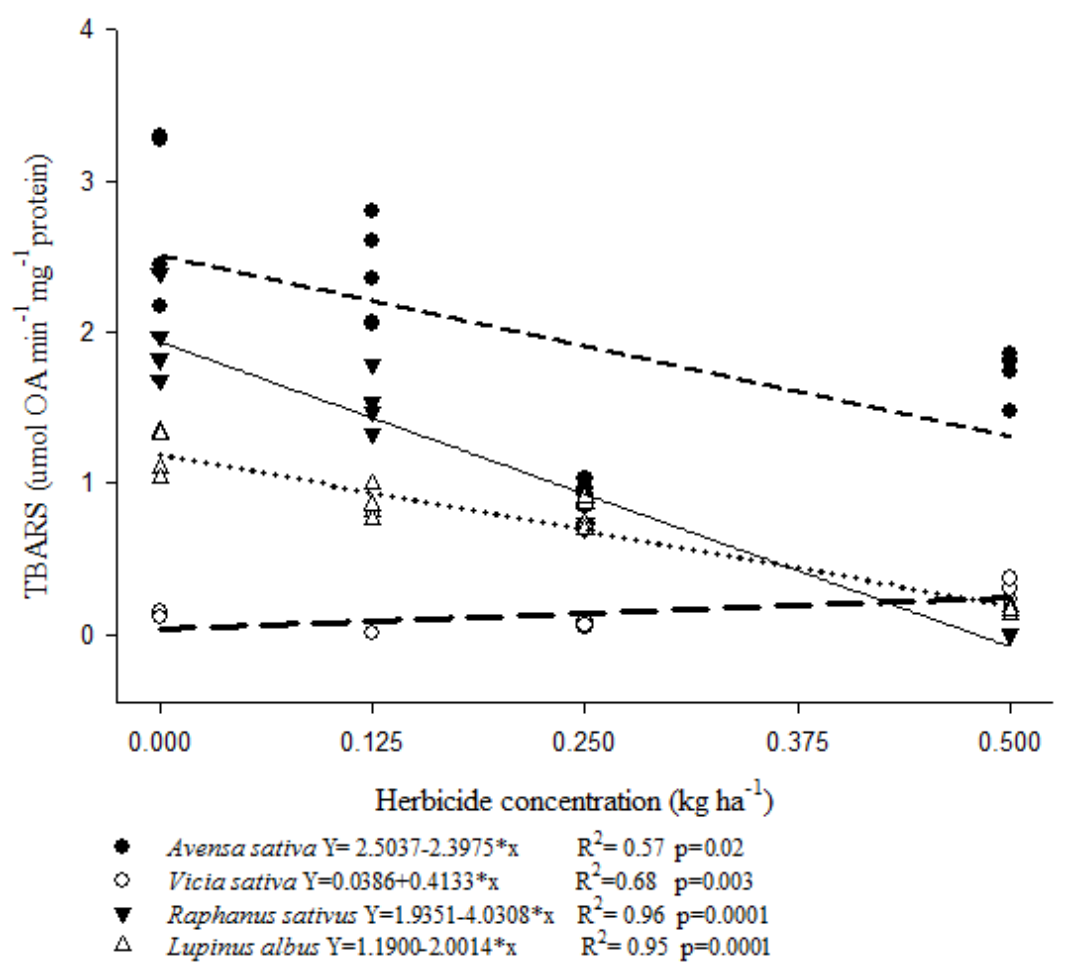

Figure 5 - Effect of fomesafen on lipid peroxidation in different crop plants.

\section{Sulfentrazone}

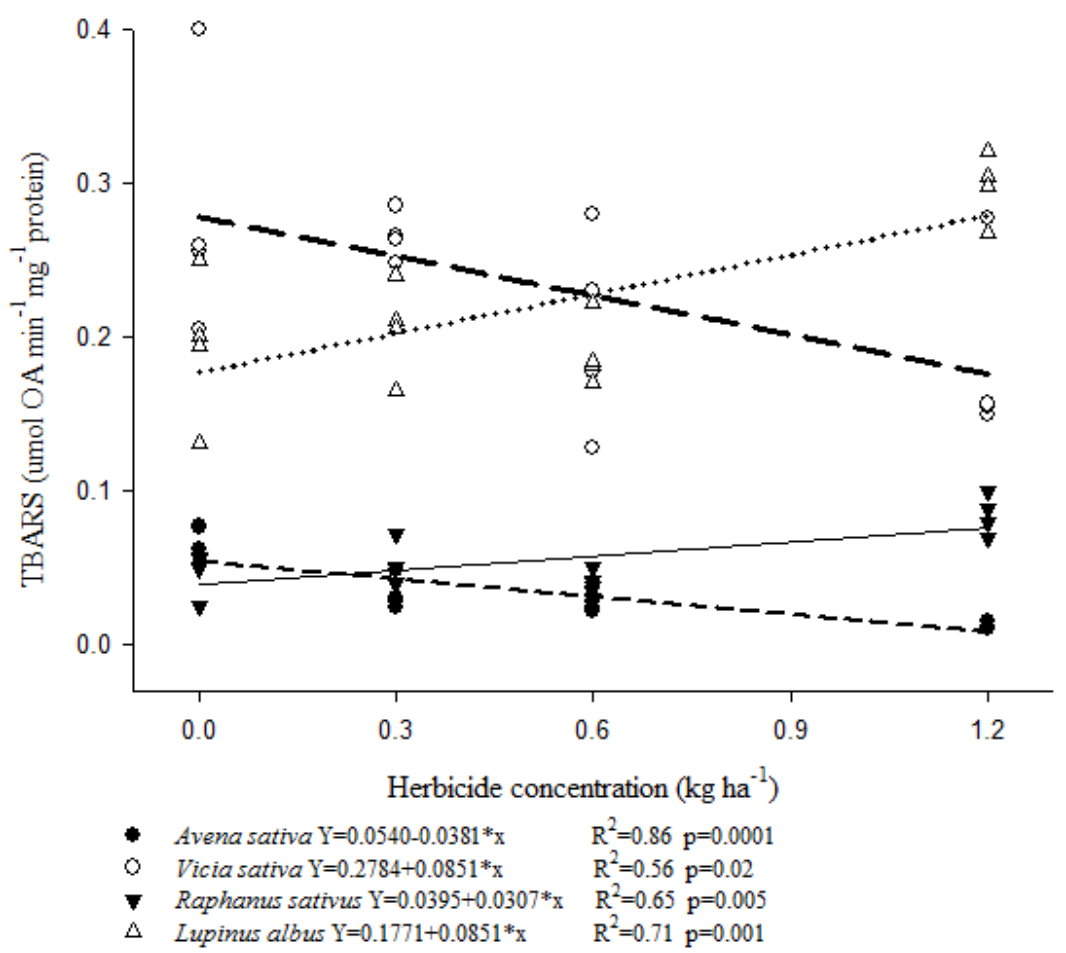

Figure 6 - Effect of sulfentrazone on lipid peroxidation in different crop plants. 


\section{Fomesafen}

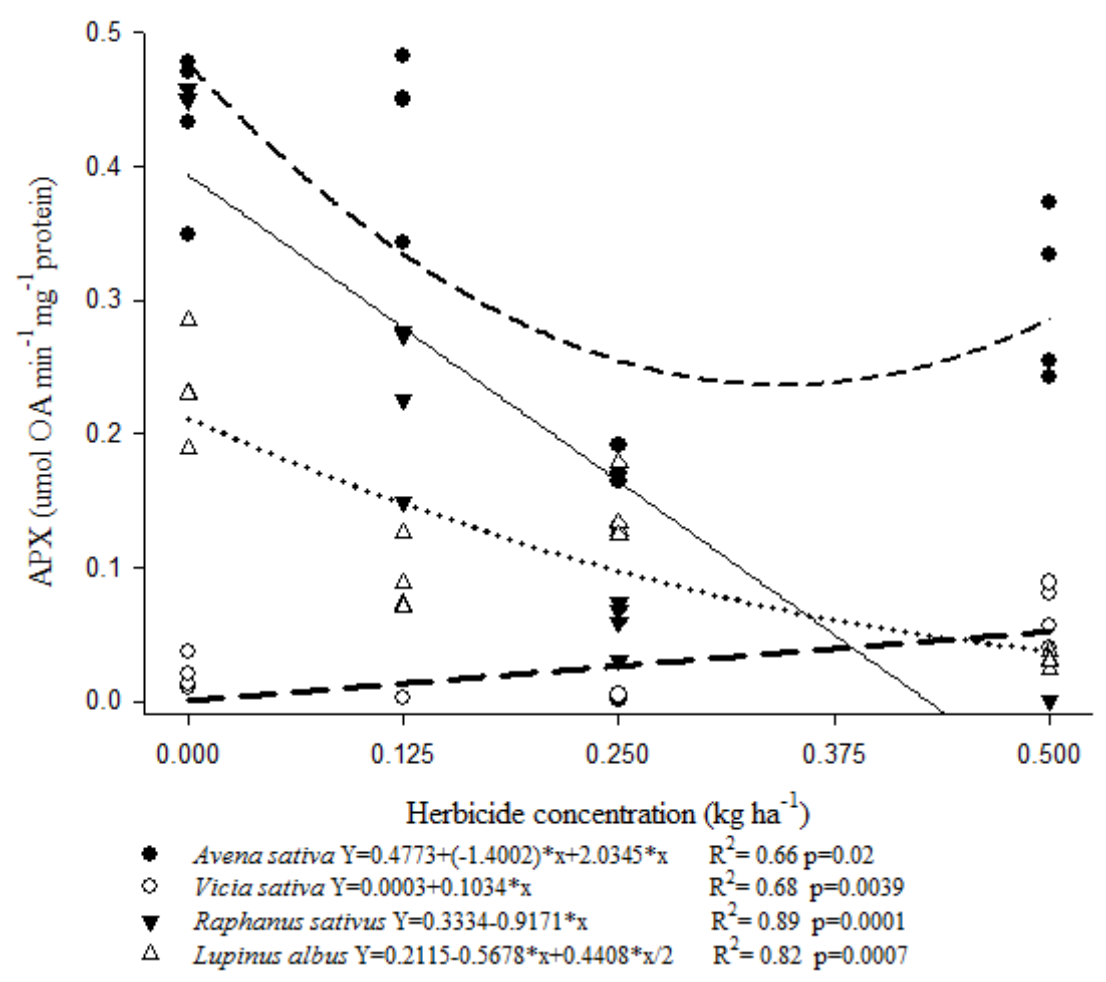

Figure 7 - Effect of fomesafen on Ascorbate peroxidase (APX) activity in different crop plants.

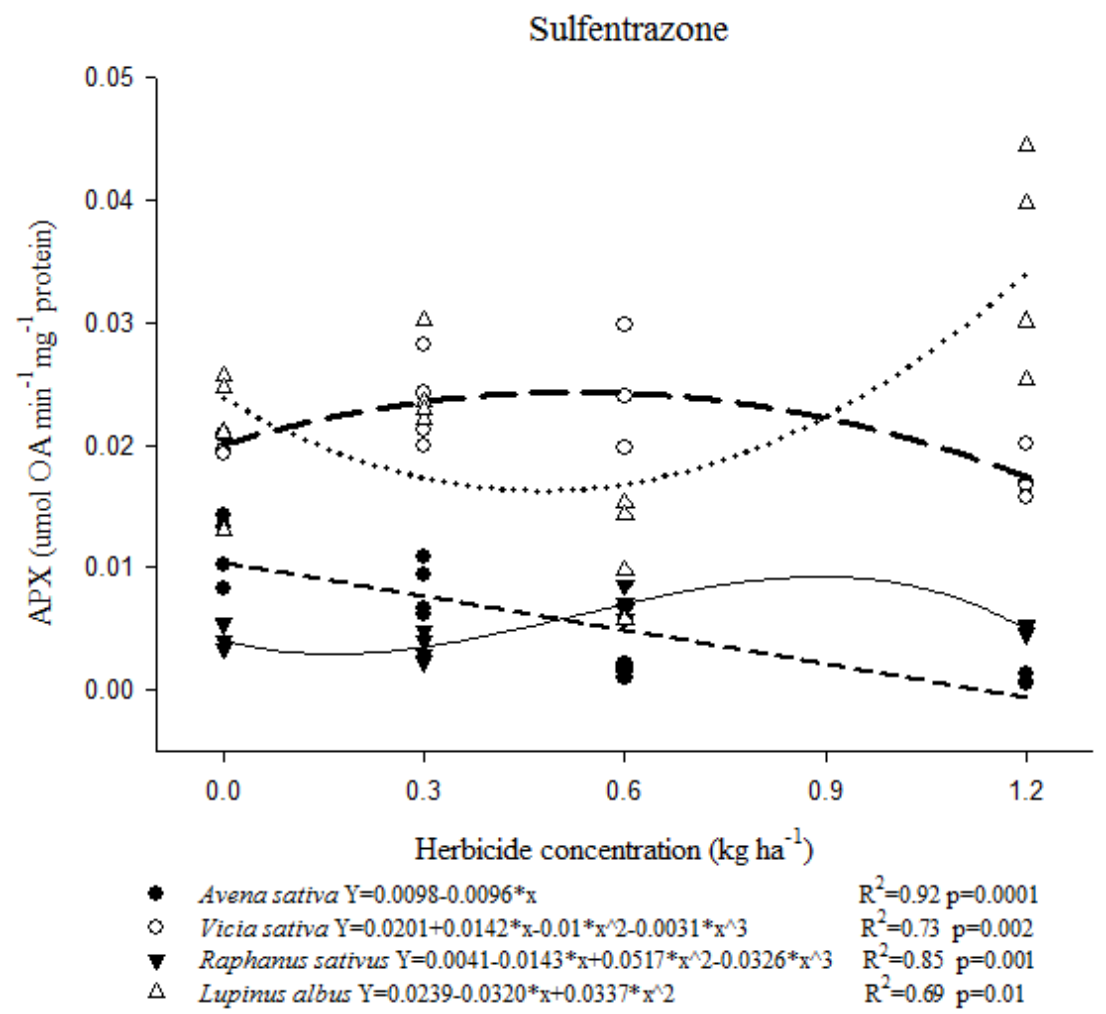

Figure 8 - Effect of sulfentrazone on Ascorbate peroxidase (APX) activity in different crop plants. 
CAT can convert 6 million molecules of $\mathrm{H}_{2} \mathrm{O}_{2}$ to $\mathrm{H}_{2} \mathrm{O}$ and $\mathrm{O}_{2}$ per minute. CAT is important in the removal of $\mathrm{H}_{2} \mathrm{O}_{2}$ generated in peroxisomes by oxidases involved in $\beta$-oxidation of fatty acids, photorespiration and purine (Agostinetto et al. 2016). After fomesafen exposure, outcomes show a decrease in the CAT enzyme activity, which directly related to the increase in the lipid peroxidation. In this scenario, $V$. sativa shows and uptake in the lipid peroxidation, that can be because the loss in the antioxidant system, due the stress cause by fomesafen. Actually, sulfentrazone was not be able to cause the lipid peroxidation, considering the species $V$. sativa shows an increased in the CAT activity and in the levels of MDA. Moreover, after exposure fomesafen CAT activity increased 213\% in the dose of $0.5 \mathrm{~kg} \mathrm{ha}^{-1}$ for A. sativa.

Sulfentrazone was responsible for an increase in GPX activity in A. sativa. This herbicide cause a decrease in GPX activity in all concentrations applied in L. albus. In corroboration, some studies showed that herbicides exposure was accompanied by the significant enhancing both CAT and GPX activities in maize roots and leaves. It well known that the presence of a few enzymes with the same catalytic function expands the plant organism adaptable possibilities, which are very important to sustain the vital functions under stress. Consequently, maize plants adaptation to soil herbicides was associated with the induction of catalase and peroxidase pathway of $\mathrm{H}_{2} \mathrm{O}_{2}$ scavenging (Kordyum et al. 2005, Grigoryuk et al. 2016).

This result is very promisor considering the $A$. sativa is most commonly used as a green manure, so the CAT activity increased the plant defense against residual herbicides.

In association, $\mathrm{APX}$ enzyme $\mathrm{H}_{2} \mathrm{O}_{2}$-scavenging in plants converts $\mathrm{H}_{2} \mathrm{O}_{2}$ to $\mathrm{H}_{2} \mathrm{O}$ using ascorbate as an electron donor (Pereira et al. 2011). In this study, was demonstrated a decrease of APX when increase the concentration of sulfentrazone in all green manure species evaluated.
Generally, dysfunction on the antioxidant system results in establishment the oxidative stress, which could be progresses to lipid peroxidation. In fact, MDA considered a good marker for the structural integrity of membranes, for indicating the level of damage to lipids by oxidation reactions (Ekmekci and Terzioglu 2005). For plants who has the rises dry weight, in previous results, (data not show), $A$. sativa, $R$. sativus and L. albus show the lower levels of lipid peroxidation when submitted to fomesafen high doses. One other hand, for sulfentrazone just $A$. sativa decreased the levels of MDA.

Several studies demonstrated the effects of herbicides bentazon, clodinafop, iodosulfuron, metribuzin, metsulfuron and 2,4-D under Rhapanus sativus show an increase in CAT activity, when 2,4-D was applied. Lipid peroxidation shows no difference between herbicides. MDA accumulation in absolute values was observed in the treatments with metsulfuron and 2,4-D (Agostinetto et al. 2016).

Results demonstrate antioxidant defense system negatively affected by fomesafen and sulfentrazone to lipid peroxidation. A. sativa demonstrated less affected by these herbicides. Increasing fomesafen and sulfentrazone concentration induced increase in reactive oxygen species levels in the plant. Increased production of reactive oxygen species, especially under higher fomesafen and sulfentrazone concentrations $(\geq$ $0.25 \mathrm{~kg} \mathrm{ha}^{-1}$ and $0.6 \mathrm{~kg} \mathrm{ha}^{-1}$ ) could weaken the antioxidant defense system. Thus, taken together the results we can suggest that the herbicides affect the green manure species, A. sativa, $V$. sativa, $R$. sativus and L. albus.

\section{CONCLUSIONS}

Taken together, the outcomes can suggest that both herbicides promoted alterations on plant homeostasis eliciting the response of the antioxidant system of plants, mainly in the high doses of fomesafen, for the species $V$. sativa and $R$. 
sativus. Here, we found the dose dependent effect to fomesafen to CAT, APX and GPX activities in A. sativa, V. sativa, $R$. sativus and L. albus. At same time, at $1.2 \mathrm{~kg} \mathrm{ha}^{-1}$ dose of sulfentrazone had inhibition of antioxidant enzymes for $V$. sativa, $R$. sativus and $L$. albus. Thus, we can suggest that this herbicide, sulfentrazone, generates oxidative stress. Additionally, A. sativa was the species that demonstrated low alterations on antioxidant system with the exposure to herbicide fomesafen and sulfentrazone.

\section{ACKNOWLEDGMENTS}

The authors wish to thank the Conselho Nacional de Desenvolvimento Científico e Tecnológico (CNPq), Coordenação de Aperfeiçoamento de Pessoal de Nível Superior (CAPES) and Fundação de Amparo à Pesquisa do Estado do Rio Grande do Sul (FAPERGS) for the financial support. So gratefull to Luciane A. Tabaldi, for helping and contribution.

\section{REFERENCES}

AEBI H. 1984. Catalase in vitro. Methods Enzymol 105: 121126.

AGOSTINETTO D, PERBONI LT, LANGARO AC, GOMES J, FRAGA DS AND FRANCO JJ. 2016. Changes in photosynthesis and oxidative stress in wheat plants submmited to herbicides application. Planta Daninha 34: $1-9$.

APEL K AND HIRT H. 2004. Reactive Oxygen Species: Metabolism, Oxidative Stress, and Signal Transduction. Annu Rev Plant Biol 55: 373-399.

CAVALCANTI FR, OLIVEIRA JTA, MARTINS-MIRANDA AS, VIÉGAS RA AND SILVEIRA JAG. 2004. Superoxide dismutase, catalase and peroxidase activities do not confer protection against oxidative damage in saltstressed cowpea leaves. New Phytol 163: 563-571.

EKMEKCI Y AND TERZIOGLU S. 2005. Effects of oxidative stress induced by paraquat on wild and cultivated wheats. Pestic Biochem Physiol 83: 69-81.
EL-MOSHATY FIB, PIKE SM, NOVACKY AJ AND SEHGAL OP. 1993. Lipid peroxidation and superoxide production in cowpea (Vigna unguiculata) leaves infected with tobacco ringspot virus or southern bean mosaic virus. Physiol Mol Plant Pathol 43: 109-119.

EMBRAPA - EMPRESA BRASILEIRA DE PESQUISA AGROPECUÁRIA. 2013. Empresa Brasileira de Pesquisa Agropecuária. Sistema brasileiro de classificação de solos. Brasília: Embrapa Produção de Informação; Brasília, DF: Embrapa Solos, 154 p.

GARG N AND MANCHANDA G. 2009. ROS generation in plants: Boon or bane? Plant Biosyst 143: 81-96.

GILL SS AND TUTEJAN. 2010. Reactive oxygen species and antioxidant machinery in abiotic stress tolerance in crop plants. Plant Physiol Biochem 48: 909-930.

GRIGORYUK IP, LYKHOLAT UV, ROSSYKHINAGALYCHA GS, KHROMYKH NO AND SERGA OI. 2016. Effect of soil herbicides on the antioxidant system of maize vegetative organs during ontogenesis. Ann Agrar Sci 14: 95-98.

KORDYUM EL, SYTNIK RM AND BARANENKO V. 2005. Cells mechanisms of plant adaptation to the adverse environmental factors at natural conditions, p. 278.

MATEUS GP, CRUSCIOL CAC AND NEGRISOLI E. 2004. Palhada do sorgo de guiné gigante no estabelecimento de plantas daninhas em área de plantio direto. Pesqui Agropecu Bras 39: 539-542.

OLIVEIRA TK, CARVALHO GJ AND MORAES RNDS. 2002. Plantas de cobertura e seus efeitos sobre o feijoeiro em plantio direto. Pesq Agropec Bras, Brasília 37: 10791087.

PEREIRA LB ET AL. 2011. Differential responses of oat genotypes: Oxidative stress provoked by aluminum. BioMetals 24: 73-83.

ROLAS. 2016. Rede oficial de laboratórios de análise de solo e de tecido vegetal. Manual de calagem e adubação para os estados do Rio Grande do Sul e Santa Catarina. $11^{\text {a }}$ ed., Porto Alegre: S.B.C.S., 376 p.

SINDIVEG. 2016. Importações de defensivos agrícolas têm aumento no primeiro semestre de 2016. In: Sind. Nac. da Indústria Prod. Para Def. Veg.

ZERAIK AE, SOUZA FS DE, FATIBELLO-FILHO O AND LEITE OD. 2008. Desenvolvimento de um spot test para o monitoramento da atividade da peroxidase em um procedimento de purificação. Quím Nov 31: 731-734.

ZHU Z, WEI G, LI J, QIANA Q AND YU J. 2004. Silicon alleviates salt stress and increases antioxidant enzymes activity in leaves of salt-stressed cucumber (Cucumis sativus L.). Plant Sci 167: 527-533. 